\title{
Processes in Bahasa Indonesia Tourism Promotion Texts and Its Equivalence in English: A Systemic Functional Linguistic Study
}

\author{
Eva Tuckyta Sari Sujatna ${ }^{1}$ \\ ${ }^{1}$ Department of Linguistics, Faculty of Cultural Sciences, Universitas Padjadjaran, Indonesia \\ Correspondence: Eva Tuckyta Sari Sujatna, Department of Linguistics, Faculty of Cultural Sciences, Universitas \\ Padjadjaran, Indonesia. E-mail: eva.tuckyta@unpad.ac.id
}

Received: June 14, 2016 Accepted: July 8, 2016 Online Published: July 28, 2016

doi:10.5539/ijel.v6n4p227 URL: http://dx.doi.org/10.5539/ijel.v6n4p227

\begin{abstract}
Many researchers do research on processes in English but it is still limited research on Bahasa Indonesia and its equivalence in English. It is necessary to do research processes in Bahasa Indonesia since it has two different types of clauses: verbal clauses and nonverbal clauses. This paper tries to figure out the processes on Bahasa Indonesia, especially on Bahasa Indonesia tourism promotion texts and its equivalence in English. The aims of the research are to describe the dominant of the processes found in the Bahasa Indonesia tourism promotion texts and to describe the verb used in each type of the processes and its equivalence in English. The research method employed in the research is descriptive method. The data collected are divided into major types of clauses: verbal clauses and nonverbal clauses. The data analyzed are the verbal clauses in Bahasa Indonesia since the verb as the main part of process then compared to its equivalence in English. The result of the research shows there are four types of processes found in both Bahasa Indonesia tourism promotion texts and its equivalence: material, relational, mental, and existential processes. The dominant process found is material processes $51.7 \%$, followed by relational processes $21.9 \%$, mental process $18.5 \%$, and existential process $7.9 \%$. The participants involved are: agent and goal (material process), carrier and attribute (relational process), experiencer and phenomenon (mental process), and existent (existential process). The verbs used in material process in Bahasa Indonesia are tenggelam, berkunjung mencari, dipadu, akan menemani, menyajikan, menjanjikan memberikan, menyimpan, menyuguhkan, memanjakan, berlabuh, menutup, melancong, membentuk, memberi, dapat membeli, memecah, dapat memesan, menyediakan, terabaikan, dapat ditempuh, dikirimkan, dilakukan, digunakan while its equivalence in English are set, visit to look for, were combined, will accompany, serve, promise to give, put, serve, spoil, anchor, can close, visit, shape, give, can buy, break, can order, serve, was ignored, can be through, were sent, can be done, is used. The relational process in Bahasa Indonesia are adalah, berasal dari, memiliki, mempunyai, mengandung, bisa menjadi, tampak, menyerupai, merupakan, berada, terletak, berlokasi and its equivalence in English are is, comes from, have, contain, can become, seem, like, become, is, is located. The mental process in Bahasa Indonesia are dapat menikmati, terpukau, melihat, terdengar and its equivalence in English are can enjoy, will be mesmerized, can see, heard. The existential processes in Bahasa Indonesia are ada, terdapat, tersedia, and its equivalence in English is be.
\end{abstract}

Keywords: processes, material processes, mental processes, relational processes, existential processes, Bahasa Indonesia

\section{Introduction}

Bahasa Indonesia is one of the Austronesia languages. It is spoken by about 250 million Indonesia people since it is used as the official language in Indonesia.

Bahasa Indonesia is different from English. In English, every clause has a verb and it happens to other European languages. In Bahasa Indonesia, there are two types of clauses: verbal clauses and nonverbal clauses. Similar to English, the verbal clause has a predicate containing a verb while the nonverbal clause has a predicate containing a noun, an adjective, or an adverb.

According to Martin, Matthiessen, \& Painter "Functional grammar is a way of looking at grammar in terms of how grammar is used" (1997). In line with Halliday (1985) in his well-known book "An Introduction to Functional Grammar" and Bloor \& Bloor (2004) introduced the three types of clauses: clause as message, clause as exchange, and clause as representation. The clause as message is about theme and rheme, while the clause as 
exchange is about mood and residue. The clause as representation is about transitivity. The transitivity discusses three elements (Halliday \& Matthiessen, 2004) in (Sujatna, 2012). They are process, participant, and circumstantial. The process as the main element is realized by a verb. Since a clause in English has a verb, every clause in English has a process. It is not similar to Bahasa Indonesia, since Bahasa Indonesia has verbal and nonverbal clauses. It means that not all clauses Bahasa Indonesia have processes. To identify the clauses containing processes, in this research, the present writer limits the type of the clauses; the verbal clauses in Bahasa Indonesia as the data and its equivalence in English.

The data obtained from the tourism promotion texts in Bahasa Indonesia. The text documents have the two features of information; logical events of cause-effect relationship and logical events of the argument and statement of historical characters (Biber \& Conrad, 2009). As Sukma \& Sujatna argue that "Every writer interacts with readers in their texts" (2014). The present writer chooses the tourism promotion text, in terms of knowing how Indonesian writers try to convince the readers in understanding their promotion in relating to the choice of processes in their clauses, especially in Bahasa Indonesia.

\subsection{Research Questions}

The followings are the three main questions discussed in this research:

1) What processes found in Bahasa Indonesia tourism promotion texts and its equivalence in English?

2) What participants involved in Bahasa Indonesia tourism promotion texts and its equivalence in English?

3) What verbs used as the main part of the process in each clause containing process in Bahasa Indonesia tourism promotion texts and its equivalence in English?

\subsection{Objectives of the Research}

The objectives of the research are:

1) To analyze and describe the processes found in Bahasa Indonesia tourism promotion texts and its equivalence in English.

2) To analyze and describe the participants involved in Bahasa Indonesia tourism promotion texts and its equivalence in English.

3) To analyze and describe the verbs used as the main part of the process in each clause containing process in Bahasa Indonesia tourism promotion texts and its equivalence in English.

\section{Method}

The method employed in the research is descriptive method. According to Bhattacherjee (2012), "Descriptive research is directed at making careful observations and detailed documentation of a phenomenon of interest. These observations must be based on the scientific method (i.e., must be replicable, precise, etc.), and therefore, are more reliable than casual observations by untrained people".

The first step, the present writer identifies the verbal and nonverbal clauses in Bahasa Indonesia tourism promotion texts and its equivalence in English. The second, the verbal clauses are classified into the types of the verb as the main part of the processes. They are classified into the six types of processes: material process, mental process, verbal process, relational process, behavioral process, and existential process. After classifying into the types of the processes, the present writer tries to analyze the participants and circumstantial involved in the Bahasa Indonesia clauses and its translation in English. As the last step, the present writer tries to describe the dominant process found in the Bahasa Indonesia tourism promotion texts and the participants involved in the process and its equivalence in English.

\section{Theoretical Framework}

Many researchers did research on tourism promotion, but it is very limited did the research on Bahasa Indonesia tourism promotion texts related to Systemic Functional Linguistics study. The followings are some researchers did their research on tourism promotion, Sunjayadi in his article titled "Mengabadikan estetika Fotografi dalam Promosi Pariwisata Kolonial di Hindia-Belanda", discussed the role of photography in colonial tourism in the Netherlands-Indies and its influence in the process to "find Indonesia" (Sunjayadi, 2008).

According to Decrop in his article titled "The influence of message format on the effectiveness of print advertisements for tourism destinations" the effectiveness of each of these components in triggering a response by the target audience (Decrop, 2007). The three types of response are taken into account: knowledge (information), liking (attraction) and behavioral intention. From the two previous researches it is found that doing research on the processes in Bahasa Indonesia tourism promotion texts is necessary in contributing to 
Linguistics area and also tourism perspectives.

Systemic Functional Linguistics (SFL) or sometimes called Functional Grammar (FG) is an approached that introduced language as a system (Halliday, 1985) relates to Emilia "SFL starts with the most general features and proceeding step by step so as to become even more specific: a message is either about doing, or about thinking, or about being; if it is about doing, this is either plan action or action on something..." (Emilia, 2014).

SFL or FG introduces language as a system of meaning. As Gerot \& Wignell argue, "Functional grammars view language as a resource for making meaning. These grammars attempts to describe language in actual use and so focus on text and their contexts." (Gerot \& Wignell, 1995)

\subsection{Metafunctions}

This approach concerns clause in three different metafunction of meanings, they are ideational, interpersonal, and textual meaning (Halliday \& Matthiessen, 2004). The ideational meaning relates to transitivity or clause as representation, interpersonal meaning relates to mood and residue or clause as message, and textual meaning relates to theme or clause as exchange. From the three metafunction of meanings, this research focuses on the ideational meaning or clause as representation.

\subsection{Transitivity}

Clause as representation concerns transitivity. Transitivity discusses three main elements; they are processes, participants, and circumstances.

\subsubsection{Processes}

Deterding \& Poedjosoedarmo argue "Process that is events which occurs or states that exists, participants involved in those processes, both people and things, and circumstances, such as the time or place at which the process occurred or the manner in which is done" (Deterding \& Poedjosoedarmo, 2001). Process as one of the elements of transitivity is classified into six different types of processes. Halliday \& Matthiessen divide the process into two major types: material, mental, relational as the main types and verbal, behavioral, existential process as the rest (2004). Every process is realized by a verb (Halliday \& Matthiessen, 2004) in (Sujatna, 2013). Besides the process, the transitivity elements are participants and circumstance. Participants are realized by nominal group while circumstances are realized by adverbial group or prepositional phrase (Halliday \& Matthiessen, 2004).

According to Gerot and Wignell, "Material process is a process of doing, so clauses with a material process obligatory have a doing (process) and a doer (participant)" (Gerot \& Wignell, 1995). In material process, the participant is not only the doer (actor) but also the goal. The following is the example of the material process in the English clause:

\section{(1) You can visit $\underline{\text { this beautiful place. }}$ \\ Agent Material process Goal}

The example (1) describes that the clause You can visit this beautiful place containing a material process. The verb group can visit is a process of doing (as a material process) so that the two participants: You as participant are the doer of the action and this beautiful place is the goal. The second type of process is mental process. Mental process (Sujatna, 2013, p. 39) involves feeling, thinking, perceiving, and having emotional reactions to things, as described in the following examples:
(2) $\underline{I}$
$\underline{\text { saw }}$
the sunset yesterday.
Senser Mental process
Phenomenon Circumstance

The clause I saw the sunset yesterday in the example (2) describes the verb see as a mental process, the process of perceiving. The process of perceiving see in the example above needs two participants: $I$ and the sunset. The first participant, I am the experiencer as someone who gets the experience and the sunset as the second participant is a phenomenon, while yesterday is the circumstance.

The third type of the process is relational process. Halliday argued "Relational process is a generalization of the traditional notion of 'copula' constructions" (Martin, 2011). In the relational processes the verbs involved are called relating verbs. Humphrey et al., mention that "The most common relating verbs are 'being' and 'having' verbs in their various forms, and they function to identify something, to describe the attributes of something or to classify something" (Humphrey, Love, \& Loise, 2014). The following are the examples of the relation processes in the English clauses. 


\section{(3) It is the place I told you. \\ Token Relational Process Value}

The clause is the example (3) has a verb of being, is that functions to identify the value the place I told you. The first participant, It is token and the other is value, the place I told you.

(4) $\underline{I}$

have $\quad \underline{\text { a car. }}$.

Carrier Relational Process Attribute

The clause in the example (4) shows that the process is relational. It has a verb of having, have, that functions to describe the attribute of $I$. The clause has two participants. The first participant is $I$ as a carrier and the second one is a car as an attribute.
(5) $\underline{\text { It }} \quad \underline{\text { is }}$
Carrier Relational Process
a beautiful beach ...
Attribute

The clause in the example (5) is not similar to (4) although they have the same process, relational process. In the clause (5) the verb is verb of being is, that functions to classify the kind of beach, a beautiful beach. So that the first participant is $I t$ as carrier and the second one is a beautiful beach as attribute.

The fourth type of process is verbal process. The process involves the saying verbs. According to Humphrey et al. (2014, p. 33), "Saying verbs represent process of communication in their various forms-processes that report direct or indirect speech." The followings are the examples of the saying verbs in the verbal process.
(6) $\underline{\mathrm{He}}$ said
that the scenery was very beautiful.
Sayer Verbal Process Verbiage (Clause)

The example (6) is an indirect speech. It has a verbal process in the clause He said that the scenery was very beautiful. It has a saying verb, said. The saying verb, said, needs two participants, they are $H \mathrm{e}$ as the sayer and that the scenery was very beautiful as the verbiage.

(7) "Finally, I found what I wanted", he answered.

Clause Sayer Verbal process

The example (7) is a direct report. The example in (7) has two clauses, they are 'Finally, I found what I wanted' and he answered. The verbal process is in the second clause. The verb answered is the verb of saying.

The next type is behavioral process. This process relates to two major things: psychological and physiological behavior (Gerot \& Wignell, 1995)as they stated, "Behavioural processes are processes of physiological and psychological behavior, like breathing, dreaming, snoring, smiling, hiccupping, looking, watching, listening, and pondering." The followings are the examples of the processes in the English clauses.

(8) $\underline{\mathrm{He}}$ snores.

Behaver Behavioral Process

The example (8) shows that the clause containing the behavioral process. The verb involved is snores. The verb snores is classified into physiological behavior.

(9) $\underline{\mathrm{He}}$ is smiling at me.

Behaver Behavioral Process Circumstance

The example (9) is a clause containing a behavioral process. The verbal group is smiling and it is classified into psychological behavior. The participant involved is only one, He as the behaver and the circumstance is at me.

The sixth type, as the last type of process is existential process. The existential processes represent experience by positing that "there was/ is something" (Eggins, 1994, p. 254).

(10) There $\underline{\text { is }} \quad$ a stain on your dress.

Existential Process Existent Circumstance

The example (10) shows that the verb is in the clause there is a stain on your dress is the existential process. The participant involved is existent. The word there is a dummy subject or sometimes called an introductory.

\subsubsection{Participants}

According to Sujatna, "Participants are expressed by noun groups (including pronouns)" (2013). Besides agent and goal in material processes, there are other participants involved in this processes. They are initiator, 
beneficiary, and scope. Agent is the participant that doing the action (the process), and it is the main participant of the process. A goal is an entity that is brought into being by the process (Matthiessen, Teruya, \& Lam, 2010).

Initiator is a participant that initiates the agent to do the process. Beneficiary as another participant in material process is a participant that gets benefit of the process. The last participant, the scope, is a unique participant; it is a nominalization of the verb in material process. The participants are described in the following examples.
(11) $\underline{\mathrm{He}}$ made me paint the room.
Initiator Material Process Agent Material Goal
(12) They made me a cake.
Agent Material Process Beneficiary Goal
(13) She took a bath in my bathroom.
Agent Material Process Circumstance

In mental process, the main participants are experiencer and phenomenon. Besides experiencer, or sometimes called senser, and phenomenon, the other participant is inducer. Inducer is the participant who induces the senser to do the process, as described in the following example.

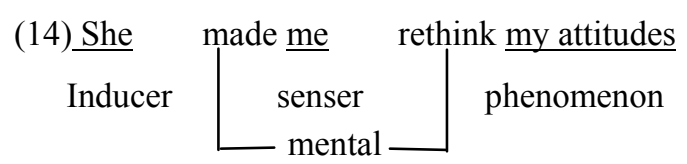

In relational processes, there are two types of processes: identifying and attributive. In identifying, the participants are token and value while in the attributive, the participants are carrier and attribute. Besides token/ value and carrier/ attribute, the other participants are attributor or and assigner, as described in the following.

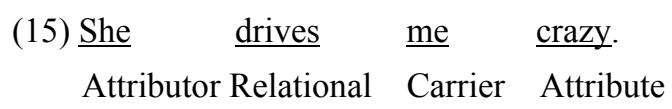

(16) $\underline{\text { They }} \underline{\text { call }} \underline{\text { me }}$ Bruce.

Assigner Relational Value Token

In verbal, behavioral, and existential processes, the participants have been discussed in the processes above, they have no additional participants.

\subsubsection{Circumstances}

Circumstance is the third element of transitivity. Circumstances can a word, a group, or a clause. It usually comes before or after the processes as described in the following examples.
(17) Yesterday I visited my grandma.
Circumstance Participant Process Participant
(18) I visited my grandma yesterday.
Participant Process Participant Circumstance

From the examples (17) and (18), it can be seen that yesterday as the circumstances can come before or after the process.

\subsection{Bahasa Indonesia Clauses}

As one of the Austronesian languages, Bahasa Indonesia is the official language in Indonesia. Bahasa Indonesia is different from English. Bahasa Indonesia has two different types of clauses: verbal clauses and nonverbal clauses.

\subsubsection{Verbal Clauses}

Verbal clause is one of the two types of clauses in Bahasa Indonesia. Verbal clauses have a verb in every clause, it is similar to English. The following is the example of verbal clause in Bahasa Indonesia.

(19) Adik pergi ke Jakarta kemarin.

sister/brother go to Jakarta yesterday

"My sister/ brother went to Jakarta yesterday." 


\begin{tabular}{lll}
\hline Adik & pergi & ke Jakarta kemarin \\
\hline Participant & Process & Circumstances \\
\hline
\end{tabular}

Verbs are the main element of the process, so that the data collected in this research are verbal clauses. It is indicated by the word pergi as the verb of the clause.

\subsubsection{Nonverbal Clauses}

Nonverbal clauses mean to the clauses which have no verbs. Since the predicate of the clauses have no verbs, the predicate of the nonverbal clauses can be a noun/ nominal, an adjective/ adjectival, an adverb/ adverbial, or a numeral as described in the following examples:

(20) Ia penulis.

he writer

"He is a writer."

(21) Aminah cantik.

Aminah beautiful

"Aminah is beautiful."

(22) Ulang tahunnya kemarin.

birthday his yesterday

"Yesterday was his birthday."

(23) Anaknya dua .

children her two

"She has two children."

The fourth examples describe Bahasa Indonesia nonverbal clauses. From the examples (20)-(23), it is described a noun penulis as predicate (20), an adjective cantik as predicate (21), an adverb kemarin as predicate (22), and a numeral $d u a$ as predicate (23).

The nonverbal clauses in Bahasa Indonesia are not discussed in this paper, since they have no verbs. This paper discussed Bahasa Indonesia verbal clauses since the verbal clauses have verbs as the main part of the processes.

\section{Results and Discussion}

The present writer analyzes 43 data (as the samples) from the 151 collected data. The data described in the following are divided into the four different types of processes: material processes, relational processes, mental processes, and existential processes as described in the following.

\subsection{Material Processes}

Material processes or process of doing is found as the dominant processes in Bahasa Indonesia Tourism Promotion text and its equivalence in English. From the data analyzed, it is found that there are 78 data of the material processes from 151 data and the present writer only analyzes 23 data from 78 data. Relating to the type of the data, the present writer classifies the data into the structure of the clauses. Relating to the pattern of the clauses, the data are classified into nine different patterns; (i) agent - process, (ii) agent - process-goal, (iii) agent - process - circumstance, (iv) agent - process - goal - circumstance, (v) agent -process-benefactive-circumstance, (vi) circumstance - agent-process-goal, (vii) goal - process-circumstance, and (viii) goal - process - agent circumstance.

\subsubsection{Agent-Process}

The present writer classifies the agent-process as the first classification. The data shows that the clause contains of two words: Matahari as the agent and tenggelam as the process, as described in the following data.

\section{(1) Matahari tenggelam.}

sun set

"The sun sets." 
Bahasa Indonesia

English

\begin{tabular}{ll}
\hline Matahari & tenggelam \\
\hline Participant: Agent & Process: Material \\
\hline
\end{tabular}

\begin{tabular}{ll}
\hline The sun & sets \\
\hline Participant: Agent & Process: Material \\
\hline
\end{tabular}

The present writer found one data consisting material process (tenggelam) preceded by an agent (Matahari) as the participant. The verb tenggelam is a process of doing so that the participant is who does the action, Matahari, is the agent of the action.

The present writer found the equivalence in English also has a material process (sets) which preceded by an agent (The sun) as the participant. The verb tenggelam (the equivalence is sets) is a process of doing so that the participant is who does the action, Matahari (the equivalence is The sun), is the agent of the action. Both Bahasa Indonesia and English have the same two elements: agent as the participant and material as the process.

\subsubsection{Agent-Process-Goal}

The second classification of the clause structure containing material process is agent-process-goal. This classification is the dominant number of data. Both Bahasa Indonesia and English data have two participants, as the agent and the goal, as described in the following.

(2) Pantai Citepus selalu menarik wisatawan lokal berkunjung mencari kehangatan laut selatan.

beach Citepus always interesting tourist local visit look for warmness ocean Indian

"Citepus beach is always interesting for local tourists visit to look for the warmness of the Indian Ocean."

\section{Bahasa Indonesia}

\begin{tabular}{lll}
\hline Pantai Citepus & selalu menarik & wisatawan lokal berkunjung mencari kehangatan laut selatan. \\
\hline Participant: Agent & Process: Material & Participant: Goal \\
\hline
\end{tabular}

\section{English}

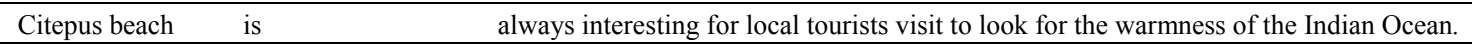

Participant: Agent Process: Relational Attribute

(3) Gugusan karang hitam berbagai bentuk dipadu pasir coklat muda.

cluster coral black many shape combine sand brown light

"Many shapes of the black coral cluster are combined with light brown sand."

\section{Bahasa Indonesia}

\begin{tabular}{lll}
\hline Gugusan karang hitam berbagai bentuk & dipadu & pasir coklat muda \\
\hline Participant: Agent & Process: Material & Participant: Goal \\
\hline
\end{tabular}

\section{English}

\begin{tabular}{lll}
\hline Many shapes of the black coral cluster & are combined & with light brown sand \\
\hline Participant: Agent & Process: Material & Circumstance \\
\hline
\end{tabular}

(4) Mulai hamparan sawah,kebun teh, sampai hutan lebatakan menemani perjalanan.

begin spread out rice field tea plantation to forest dense will accompany journey

"The spread out of rice field, tea plantation, and dense forest will accompany the journey." 
Bahasa Indonesia

\begin{tabular}{lll}
\hline Mulai hamparan sawah, kebun teh sampai hutan lebat & akan menemani & perjalanan. \\
\hline Participant: Agent & Process: Material & Participant: Goal \\
\hline
\end{tabular}

\section{English}

\begin{tabular}{lll}
\hline The spread out of rice field, tea plantation, and dense forest & will accompany & the journey. \\
\hline Participant: Agent & Process: Material & Participant: Goal \\
\hline
\end{tabular}

(5) Pantai Madasari menyajikan panorama alam yang sangat indah dengan dihiasi pulau-pulau kecil.... beach Madasari serve panoramic nature which very beautiful with decorated islands small "Madasari beach serves a beautiful panoramic nature which is decorated by small green islands ..."

\section{Bahasa Indonesia}

\begin{tabular}{lll}
\hline Pantai Madasari & menyajikan panorama alam yang sangat indah dengan dihiasi pulau-pulau kecil... \\
\hline Participant: Agent & Process: Material Participant: Goal \\
\hline
\end{tabular}

\section{English}

\begin{tabular}{lll}
\hline Madasari beach & serves & a beautiful panoramic nature which is decorated by small green islands... \\
\hline Participant: Agent & Process: Material & Participant: Goal \\
\hline
\end{tabular}

(6) Karena itu kawasan ini menjanjikan memberikan rekreasi air yang menyenangkan,

Because that area this promise give recreation water which fun seperti: Snorkling, Surving, Penyewaan Perahu, Berenang,....

like snorkling surving rental boat swimming

"Because that place promises to give a fun water recreation such as: snorkeling, surfing, boat rental swimming, ...."

\section{Bahasa Indonesia}

\begin{tabular}{lll}
\hline Karena itu kawasan ini & menjanjikan & $\begin{array}{l}\text { rekreasi air yang menyenangkan, seperti: Snorkling, memberikan Surving, Penyewaan Perahu, } \\
\text { Berenang, ... }\end{array}$ \\
\hline Conj. $\quad$ Participant: Agent & Process: Material & Participant: Goal \\
\hline
\end{tabular}

\section{English}

\begin{tabular}{|c|c|c|}
\hline Because that place & promises to give & a fun water recreation such as: snorkeling, surfing, boat rental swimming, .... \\
\hline Conj. Participant: Agent & Process: Material & Participant: Goal \\
\hline
\end{tabular}

(7) Pantai Apra ternyata juga menyimpan kekayaan alam berupa pasir besi yang berlimpah.

Pantai Apra actually also put wealth nature like sand iron which plentiful

"Pantai Apra is also wealthy of natural resource like sand iron."

\section{Bahasa Indonesia}

\begin{tabular}{lll}
\hline Pantai Apra & ternyata juga menyimpan & kekayaan alam berupa pasir besi yang berlimpah. \\
\hline Participant: Agent & Process: Material & Participant: Goal \\
\hline
\end{tabular}

\section{English}

\begin{tabular}{lll}
\hline Pantai Apra & is also & wealthy of natural resource like sand iron \\
\hline Participant: Agent & Process: Relational & Participant: Attribute \\
\hline
\end{tabular}


(8) Hamparan atol seluas 35 hektare juga menyuguhkan pemandangan menakjubkan. spread out atoll wide 35 hectare also serve scenery amazing

"The spread out of 35 hectare atoll serves amazing scenery."

\section{Bahasa Indonesia}

\begin{tabular}{lrl}
\hline Hamparan atol seluas 35 hektare juga menyuguhkan & pemandangan menakjubkan. \\
\hline Participant: Agent & Process: Material & Participant: Goal \\
\hline
\end{tabular}

\section{English}

\begin{tabular}{lll}
\hline The spread out of 35 hectare atoll & serves & amazing scenery. \\
\hline Participant: Agent & Process: Material & Participant: Goal \\
\hline
\end{tabular}

From the seven data, it can be seen that the verbs used in material processes in Bahasa Indonesia clauses are berkunjung mencari, dipadu, akan menemani, menyajikan, menjanjikan memberikan, menyimpan, and menyuguhkan while the equivalence verbs in English are visit to look for, are combined, will accompany, serve, promise to give, is, and serve. From the seven verbs are found in the seven Bahasa Indonesia clauses in tourism promotion texts, they have the same patterns; agent-process-goal while only one clause in the equivalence in English as described in the data (7). It is described that the data has different process, it contains of relational process not the material process as described in Bahasa Indonesia data.

\subsubsection{Agent-Process-Circumstance}

From the data collected, the present writer found four clauses containing agent - process - circumstance: the first two clauses the agents are explicitly stated while the third clause the agent is implicitly stated. These clauses has only one participant, agent. The processes are represented by the verbs memanjakan, berlabuh,menutup, and melancong in Bahasa Indonesia verbs and spoil, anchor, have closed, and visit in English as its equivalence as described in the following examples.

(9) Fasilitas tersebut untuk memanjakan anda yang ingin bersantap ....

facility the to spoil you that want eat

"The facility spoils you who want to enjoy your lunch ...."

\section{Bahasa Indonesia}

\begin{tabular}{lll}
\hline Fasilitas tersebut & untuk memanjakan & anda yang ingin bersantap .... \\
\hline Participant: Agent & Process: Material & Participant: Goal \\
\hline
\end{tabular}

\section{English}

\begin{tabular}{lll}
\hline The facility & spoils & you who want to enjoy your lunch ..... \\
\hline Participant: Agent & Process: Material & Participant: Goal \\
\hline
\end{tabular}

(10) Ratusan perahunelayan berlabuh disana dengan membawahasil tangkapan ikannya. hundreds boat fisherman anchor over there with bring result catch fish "Hundreds of fisherman boats anchor over there by bringing their fish."

\section{Bahasa Indonesia}

\begin{tabular}{lll}
\hline Ratusan perahu nelayan & berlabuh & di sana dengan membawa hasil tangkapan ikannya. \\
\hline Participant: Agent & Process: Material & Circumstance \\
\hline
\end{tabular}

\section{English}

\begin{tabular}{lll}
\hline Hundreds of fisherman boats & anchor & over there by bringing their fish. \\
\hline Participant: Agent & Process: Material & Circumstance \\
\hline
\end{tabular}


(11) "Kita juga sempat menutup hingga satu bulan karena curah hujan cukup tinggi." we also time close up to one month because rainfall enough high

"We also have closed the place for about one month because of the rainfall is high enough."

Bahasa Indonesia

\begin{tabular}{lll}
\hline Kita juga & sempat & menutup hingga satu bulan karena curah hujan cukup tinggi. \\
\hline Participant: Agent & Process: Material & Circumstance \\
\hline
\end{tabular}

English

\begin{tabular}{lll}
\hline We & also have closed & for about one month because of the rainfall is high enough. \\
\hline Participant: Agent & Process: Material & Circumstance \\
\hline
\end{tabular}

(12) Jika melancong ke Santolo,....

if visit to Santolo

"If you visit to Santolo, ..."

Bahasa Indonesia

\begin{tabular}{lll}
\hline Jika (anda) & melancong & ke Santolo.... \\
\hline Conj. Participant: Agent & Process: Material & Circumstance \\
\hline
\end{tabular}

\section{English}

\begin{tabular}{llll}
\hline If & you & visit & to Santolo,... \\
\hline Conj. & Participant: Agent & Process: Material & Circumstance \\
\hline
\end{tabular}

The first three clauses above describe that the verbs memanjakan, berlabuh, and menutup are the processes of doing followed by the circumstances. The agents are stated explicitly. It happens to the equivalence in English, the four clauses (containing the verbs spoil, anchor, have closed, and visit). It is different from the third data (12) in Bahasa Indonesia, the agent is not stated. Implicitly, the agent of the data (12) is Anda "you" as the reader of the message.

\subsubsection{Agent-Process-Goal-Circumstance}

The present writer found the next classification is agent-process-goal-circumstance. For this structure, the present writer found one verb, membentuk in Bahasa Indonesia and its equivalence in English is shape as described in the following clauses.

(13) Lautnya terbentang luas membentuk garis horizon di kaki langit biru dengan deburan ombaknya yang khas. sea spread out wide shape line horizon in foot sky blue with splashing wave which unique "The wide sea shapes a horizon line in the foot of the blue sky with the sound of unique wave splashing."

\section{Bahasa Indonesia}

\begin{tabular}{llc}
\hline Lautnya terbentang luas & membentuk & garis horizon di kaki langit biru dengan deburan ombaknya yang khas. \\
\hline Participant: Agent & Process: Material Participant: Goal Circumstance \\
\hline
\end{tabular}

\section{English}

\begin{tabular}{llll}
\hline The wide sea & shapes & a horizon line & in the foot of the blue sky with the sound of unique wave splashing. \\
\hline Participant: Agent & Process: Material & Participant: Goal & Circumstance \\
\hline
\end{tabular}

The verb membentuk in the clause (13) has two participants. The participants in the clause (13) are the wide sea as the agent and a horizon line as the goal while di kaki langit biru dengan deburan ombaknya yang khas is the circumstance. 


\subsubsection{Agent-Process-Beneficiary-Goal}

The present writer found one data containing three participants in material process: agent, benefctive, and goal as described in data (14) in Bahasa Indonesia containing the verb memberi. In the clause (14) it is shown that the participant Pandangan lepas ke ujung cakrawala as the agent of the action and Anda is the beneficiary of the action memberi and the third participant, the goal, is ketenangan dan kenangan berlibur yang menyenangkan.

(14) Pandangan lepas ke ujung cakrawala memberi Anda ketenangan dan kenangan berlibur yang menyenangkan view free to tip horizon give you composure and memory holiday which excited "The horizon view gives you composure and memory of an excited holiday."

\section{Bahasa Indonesia}

\begin{tabular}{lll}
\hline Pandangan lepas ke ujung cakrawala memberi & Anda ketenangan dan kenangan berlibur yang menyenangkan. \\
\hline Participant: Agent & Process: Material & Participant: Goal \\
\hline
\end{tabular}

\section{English}

\begin{tabular}{lll}
\hline The horizon view & gives & you composure and memory of an excited holiday. \\
\hline Participant: Agent & Process: Material & Participant: Goal \\
\hline
\end{tabular}

The equivalence in English in data (14) described that the verb give in English is the equivalence of the verb memberi in Bahasa Indonesia. Both in English and Bahasa Indonesia, they have the same pattern, agent-process-beneficiary-goal and the same process, material process.

\subsubsection{Circumstance-Agent-Process-Goal}

From the analyzed data, the present writer found the verb dapat membeli, memecah, dapat memesan, menyediakan dan terabaikanare categorized into material processes in the circumstance-agent-process-goal clause structure in Bahasa Indonesia as described in the following data.
(15) ... pengunjung masih dapat membeli berbagai jenis...
visitor still can buy some type
"... the visitors can buy the fish ...."

Bahasa Indonesia

\begin{tabular}{cll}
\hline ...pengunjung & masih dapat membeli & berbagai jenis hasil ikan laut .... \\
\hline Participant: Agent & Process: Material & Participant: Goal \\
\hline
\end{tabular}

\section{English}

\begin{tabular}{cll}
\hline$\ldots$ the visitors & can buy & the fish .... \\
\hline Participant: Agent & Process: Material & Participant: Goal \\
\hline
\end{tabular}

(16) Debur ombak serta cipratan air saat ombak memecah batu karang....

splash wave and spray water when wave break rock coral

"Splashing of the wave and water when the wave breaks the coral ...."

\section{Bahasa Indonesia}

\begin{tabular}{lrl}
\hline Debur ombak serta cipratan air saat ombak memecah & batu karang.... \\
\hline Participant: Agent & Process: Material & Participant: Goal \\
\hline
\end{tabular}

\section{English}

\begin{tabular}{|c|c|c|}
\hline Splashing of the $\mathrm{w}$ & breaks & the coral \\
\hline Participant: Agent & Process: Material & Participant: Goal \\
\hline
\end{tabular}

(17) Di sini, pengunjung dapat memesan berbagai makanan dan olahan hasil laut,... here visitor can order various food and product result sea 
"Here the visitors can order various seafood, marine product...."

Bahasa Indonesia

Englis

\begin{tabular}{llll}
\hline Di sini & pengunjung & dapat memesan & berbagai makanan dan olahan hasil laut, ... \\
\hline Conj. & Participant: Agent & Process: Material & Participant: Goal \\
\hline & & \\
\hline Here the visitors & can order & various seafood, marine product, and lobsters. \\
\hline Conj. Participant: Agent & Process: Material & Participant: Goal \\
\hline
\end{tabular}

(18) Selain fasilitas air terjun pelangi, pengelola pun menyediakan fasilitas sebuah'cafe view deck'. besides facility water fall rainbow organizer to serve facility a cafe view deck 'Besides the facility of the water fall rainbow, the management also serves a "café view deck" facility.'

\section{Bahasa Indonesia}

\begin{tabular}{llll}
\hline \multicolumn{2}{l}{ Selain fasilitas air terjun pelangi, pengelola pun } & menyediakan & fasilitas sebuah'cafe view deck'. \\
\hline Circumstance & Participant: Agent & Process: Material & Participant: Goal \\
\hline
\end{tabular}

\section{English}

\begin{tabular}{llll}
\hline Besides the facility of the water fall rainbow, the management also & serves & a 'café view deck' facility. \\
\hline Circumstance & Participant: Agent & Process: Material & Participant: Goal \\
\hline
\end{tabular}

(19) Namun seiring perkembangan jalur angkutan darat, dermaga pun terabaikan.

but as developing of traffic land transport quay ignored

"As the developing of land transport, the quay was ignored."

\section{Bahasa Indonesia}

\begin{tabular}{lrl}
\hline Namun seiring perkembangan jalur angkutan darat, dermaga pun & terabaikan. \\
\hline Circumstance & Participant: Agent & Process: Material \\
\hline
\end{tabular}

\section{English}

\begin{tabular}{lll}
\hline As the developing of land transport, the quay & was ignored. \\
\hline Circumstance & Participant: Agent & Process: Material \\
\hline
\end{tabular}

From the five data mentioned in clauses (15)-(19), it is described that the verbs are classified into the material processes that need two participants, agent and goal. The verbs are membeli, memecah, memesan, menyediakan, berjalan-jalan, and terabaikan have the equivalence in English, can buy, break, can order, serve, and was ignored.

\subsubsection{Goal-Process-Circumstance}

The present writer found that the verb ditempuh in Bahasa Indonesia can be classified into material process as described in the data (20).

(20) Pantai Santolo yang ～berjarak sekitar 98 kilometer dari arah kota Garut dapat ditempuh dari berbagai arah... beach Santolo which distance about 98 kilo meter from direction city Garut can go through from some direction "Santolo beach is about $98 \mathrm{~km}$ from Garut city can be through from others directions, ..."

\section{Bahasa Indonesia}

\begin{tabular}{lcc}
\hline Pantai Santolo yang berjarak sekitar 98 kilometer dari arah kota Garut dapat ditempuh & dari berbagai arah... \\
\hline Participant: Goal & Process: Material & Circumstance \\
\hline
\end{tabular}




\section{English}

\begin{tabular}{lll}
\hline Santolo beach about $98 \mathrm{~km}$ from Garut city can be through & from others directions, ... \\
\hline Participant: Goal & Process: Material & Circumstance \\
\hline
\end{tabular}

From the data (20), it can be seen that the verb in the clause has no agent, it only has one participant, as a goal. The structure of the clause is goal-process-circumstance. The verb is process of doing while the participant Pantai Santolo yang berjarak sekitar 98 kilometer dari arah kota Garut is the goal of the action dapat ditempuh as the process. It happens to the equivalence in English, the clause has no agent, its pattern is goal-process-circumstance.

\subsubsection{Goal-Process-Agent-Circumstance}

The following data have similarity with the data (20) the voices are passive. The clause (20) is not classified into the following clauses since the clause (21) has one participant while the following clauses (21)-(23) have two participants as described in the following.

(21) ... karet dan teh dikirimkan Belanda ke negerinya di Eropa melalui dermaga Santolo. rubber and tea to send Dutch to country his in Europe through quay Santolo

“...rubber and tea were sent through Santolo quay by the Dutch."

Bahasa Indonesia

\begin{tabular}{cl}
\hline$\ldots$ karet dan teh $\quad$ dikirimkan & Belanda ke negerinya di Eropa melalui dermaga Santolo. \\
\hline Participant: Goal Process: Material & Participant: Agent \\
\hline
\end{tabular}

English

\begin{tabular}{lccc}
\hline$\ldots$ rubber and tea & were sent & through Santolo quay by the Dutch. \\
\hline Participant: Goal & Process: Material & Circumstance & Participant: Agent \\
\hline
\end{tabular}

(22) Banyak aktivitas pantai biasa dilakukan oleh wisatawan...

many activity beach usual do by tourist

"Many beach activities are usually done by the tourists ..."

\section{Bahasa Indonesia}

\begin{tabular}{ll}
\hline Banyak aktivitas pantai biasa dilakukan & oleh wisatawan ... \\
\hline Participant: Goal & Process: Material Participant: Agent \\
\hline
\end{tabular}

\section{English}

\begin{tabular}{lll}
\hline Many beach activities are usually done & by the tourists ... \\
\hline Participant: Agent & Process: Material & Participant: Agent \\
\hline
\end{tabular}

(23) Lokasi bekas dermaga sering digunakan warga sebagai tempat favorit memancing ikan, .... location ex quay usually used citizen as place favorite to fish "The old quay is used as a favorite place for fishing by the citizen...."

\section{Bahasa Indonesia}

\begin{tabular}{lll}
\hline \multicolumn{2}{l}{ Lokasi bekas dermaga sering digunakan } & warga sebagai tempat favoritmemancing ikan, .... \\
\hline Participant: Agent & Process: Material & Participant: Agent \\
\hline
\end{tabular}

\section{English}

\begin{tabular}{lll}
\hline The old quay & is used as & a favorite place for fishing by the citizen... \\
\hline Participant: Goal & Process: Material & Circumstance Participant: Agent \\
\hline
\end{tabular}


The three clauses above have two participants: agents and goals. The data (21) describes the verb dikirimkan is the material process preceded by the goal Kekayaan hasil bumi di wilayah selatan Garut terutama karet dan teh and followed by the word Belanda as the agent while the equivalence verb in English is were sent. It also happens to the data (22) and (23). The goal Banyak aktivitas pantai in (22) preceded the verb dilakukan (the equivalence verb is is done) and followed by the agent wisatawan and the goal Lokasi bekas dermaga in (23) is preceded by the verb digunakan (the equivalence is is used) and followed by the agent warga.

\subsection{Relational Processes: Attributive}

Relational process is the second type of process found in the Bahasa Indonesia tourism promotion texts. The data classified into relational process are 33 data while the data analyzed are 12 data. The relational processes are categorized into attributive and identifying relational processes. Relating to the analysis of the data, the present writer found attributive only. There is no identifying relational process.

(24) Yang menambah daya tarik Batu Hiu juga adalah tempat penangkaran penyu. which add interest Batu Hiu also is place sanctuary tortoise

"Something interesting from Batu Hiu is a tortoise sanctuary place."

Bahasa Indonesia

\begin{tabular}{l}
\hline Yang menambah daya tarik Batu Hiu juga adalah tempat penangkaran penyu. \\
\hline Participant: Carier Process: Material Participant: Attribute \\
\hline
\end{tabular}

English

\begin{tabular}{lll}
\hline Something interesting from Batu Hiu is & a tortoise sanctuary place \\
\hline Participant: Carier & Process: Relational & Participant: Attribute \\
\hline
\end{tabular}

(25) Sebutan Santolo sendiri berasal dari bahasa Belanda, yakni dari kata Zon (dibaca San), dan Tulu. name Santolo itself origin from language Dutch namely from word Zon (read San) and Tulu "The name Santolo comes from Dutch namely Zon (read San) and Tulu."

Bahasa Indonesia

\begin{tabular}{lll}
\hline Sebutan Santolo sendiri & berasal dari & bahasa Belanda, yakni dari kata Zon (dibaca San), dan Tulu. \\
\hline Participant: Carier & Process: Relational & Participant: Attribute \\
\hline
\end{tabular}

\section{English}

\begin{tabular}{lll}
\hline The name Santolo & comes & from Dutch namely Zon (read San) and Tulu \\
\hline Participant: Carier & Process: Relational & Participant: Attribute \\
\hline
\end{tabular}

(26) Selain itu, Anda juga memiliki alternatif berupa atraksi pantai yang sangat menyenangkan,.... besides that you also have alternative as attraction beach which very please "Beside that you have an alternative, an attraction to please you...."

\section{Bahasa Indonesia}

\begin{tabular}{llll}
\hline Selain itu, & Anda juga & memiliki & alternatif berupa atraksi pantai yangsangat menyenangkan,.... \\
\hline Conj. & Participant: Carrier & Process: Relational & Participant: Attribute \\
\hline
\end{tabular}

\section{English}

Beside that you have an alternative, an attraction to please you.... Conj. Participant: Carier Process: Relational Participant: Attribute

(27) Pantai Pananjungmempunyai area yang cukup luas dengan Koordinat.... beach Pananjung has area which enough wide with coordinate "Pananjung beach has a wide are with coordinate ...." 
Bahasa Indonesia

\begin{tabular}{lll}
\hline Pantai Pananjung & mempunyai $\quad$ area yang cukup luas dengan Koordinat... \\
\hline Participant: Carier & Process: Relational Participant: Attribute \\
\hline
\end{tabular}

\section{English}

\begin{tabular}{lll}
\hline Pananjung beach & has & a wide are with coordinate.... \\
\hline Participant: Carier & Process: Relational & Participant: Attribute \\
\hline
\end{tabular}

(28) Sumber mata air panasnya mengandung belerang yang cukup tinggi, ....

source hot spring contain sulphur which enough high

"The hot spring has high sulphur content...."

\section{Bahasa Indonesia}

\begin{tabular}{lll}
\hline Sumber mata air panasnya & mengandung & belerang yang cukup tinggi, .... \\
\hline Participant: Carier & Process: Relational & Participant: Attribute \\
\hline
\end{tabular}

\section{English}

\begin{tabular}{lll}
\hline The hot spring & has & high sulphur content.... \\
\hline Participant: Carier & Process: Relational & Participant: Attribute \\
\hline
\end{tabular}

(29) Bagi Anda yang berkunjung ke pantai utara Pulau Jawa, Pantai Tirtamaya bisa menjadi pilihan untuk berekreasi. for you which visit to beach north Pulau Jawa Pantai Tirtamaya can become choice for recreation "For you who visit to Pulau Jawa, Pantai Tirtamaya can be a choice for recreation."

\section{Bahasa Indonesia}

\begin{tabular}{cll}
\hline ..., Pantai Tirtamayabisa & menjadi & pilihan untuk berekreasi. \\
\hline Participant: Carier & Process: Relational & Participant: Attribute \\
\hline
\end{tabular}

\section{English}

\begin{tabular}{lll}
\hline$\ldots$, Pantai Tirtamaya & can be & a choice for recreation. \\
\hline Participant: Carier & Process: Relational & Participant: Attribute \\
\hline
\end{tabular}

(30) ...Karang Kukus tampak menonjol di tengah hamparan karang.

Karang Kukus seem stick out at middle spread out of coral

"Karang Kukus is stick out at the middle of the coral."

\section{Bahasa Indonesia}

\begin{tabular}{lcc}
\hline Karang Kukus & tampak & menonjol di tengah hamparan karang. \\
\hline Participant: Carier & Process: Relational & Participant: Attribute \\
\hline
\end{tabular}

\section{English}

\begin{tabular}{lll}
\hline Karang Kukus & is stick out & at the middle of the coral \\
\hline Participant: Carier & Process: Relational & Participant: Attribute \\
\hline
\end{tabular}

(31) Batu Hiu terkenal akan karang besarnya menyerupai ikan hiu.
Batu Hiu well known for coral huge
like fish shark

"Batu Hiu is well known by a huge coral like a shark." 
Bahasa Indonesia

\begin{tabular}{lll}
\hline Batu Hiu terkenal akan karang besarnya menyerupai & ikan hiu. \\
\hline Participant: Carier & Process: Relational & Participant: Attribute \\
\hline
\end{tabular}

\section{English}

\begin{tabular}{lll}
\hline Batu Hiu & is well known & by a huge coral like a shark. \\
\hline Participant: Carier & Process: Relational & Participant: Attribute \\
\hline
\end{tabular}

(32) Pantai ini merupakan pantai terlebar dan terpanjang di kawasan Pantai Selatan,...

beach this become beach widest and longest in area Indian Ocean

"This beach is the widest and longest in Indian Ocean...."

\section{Bahasa Indonesia}

\begin{tabular}{lll}
\hline Pantai ini & merupakan & pantai terlebar dan terpanjang di kawasan Pantai Selatan,... \\
\hline Participant: Carier & Process: Relational & Participant: Attribute \\
\hline
\end{tabular}

\section{English}

This beach is the widest and longest in Indian Ocean, .... Participant: Carier Process: Relational Participant: Attribute

(33) Pantai Tanjung Pakis berada di ujung Utara Karawang, .... beach Tanjung Pakis be in tip northern Karawang "Tanjung Pakis beach is in the Northern Karawang, ...."

\section{Bahasa Indonesia}

\begin{tabular}{|c|c|c|}
\hline Pantai Tanjung Paki & berada & di ujung Utara Karawang, .... \\
\hline Participant: Carier & Process: Relational & Participant: Attribute \\
\hline
\end{tabular}

\section{English}

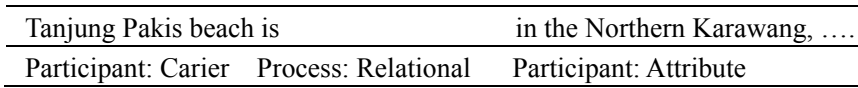

(34) Lokasi Pantai Tanjung Pakis terletak di Kecamatan Pakisjaya .... location Pantai Tanjung Pakis locate in subdistrict Pakisjaya "The location of Tanjung Pakis beach is on Pakisjaya subdistrict,...."

\section{Bahasa Indonesia}

\begin{tabular}{lll}
\hline Lokasi Pantai Tanjung Pakis terletak & di Kecamatan Pakisjaya.... \\
\hline Participant: Carier & Process: Relational & Participant: Attribute \\
\hline
\end{tabular}

\section{English}

\begin{tabular}{|c|c|c|}
\hline The location of Tan & & on Pakisjaya subdistrict, .... \\
\hline Participant: Carier & Process: Relational & Participant: Attribute \\
\hline
\end{tabular}

(35) Wisata Pemandian Alam Cipanas Cileungsing berlokasi tidak terlalu jauh dari Cipanas Sekarwangi. tourism pool nature Cipanas Cileungsi located no too far from Cipanas Sekarwangi "The hot spring Cipanas Cileungsi is not far from Cipanas Sekarwangi." 
Bahasa Indonesia

\begin{tabular}{lll}
\hline Wisata Pemandian Alam Cipanas Cileungsing & berlokasi & tidak terlalu jauh dari Cipanas Sekarwangi. \\
\hline Participant: Carier & Process: Relational & Participant: Attribute \\
\hline
\end{tabular}

\section{English}

\begin{tabular}{lll}
\hline The hot spring Cipanas Cileungsi & is not & far from Cipanas Sekarwangi. \\
\hline Participant: Carier & Process: Relational & Participant: Attribute \\
\hline
\end{tabular}

From the 33 data, the present writer analyzed and found fourteen different verbs used in the attributive relational processes. They are adalah, berasal, memiliki, mempunyai, mengandung, menjadi, menjadikan, tampak, menyerupai, merupakan, tersohor, berada, terletak, and berlokasi, as described in the data (33)-(46).

\subsection{Mental Processes}

Mental process is the second type of process found in the Bahasa Indonesia tourism promotion texts. The data classified into mental process are 28 data and the data analyzed as the samples are five. The analyzed are categorized into two major categories: process of feeling and process of perceiving. The verb in the process of feeling is dapat menikmati and menyaksikan. The verbs in the process of perceiving are melihat and terdengar.

\subsubsection{Process of Feeling}

In the process of feeling, the present writer found two verbs used in this process: the verb menikmati and menyaksikan. The present writer found the verb menikmati are 14 data (the analyzed data only one data) andakan terpukau (one data).

(36) Anda dapat menikmati keindahan alam dan hawa pengunungan yang masih sejuk....

you can enjoy beauty nature and air mountain which still fresh

"You and your family can enjoy the beauty of nature and fresh air."

\section{Bahasa Indonesia}

Anda dapat menikmati keindahan alam dan hawa pengunungan yang masihsejuk di
sini bersama keluarga.

\section{English}

\begin{tabular}{lll}
\hline You and your family can enjoy & the beauty of nature and fresh air. \\
\hline Participant: Senser & Process: Mental & Participant: Phenomenon \\
\hline
\end{tabular}

(37) Selain itu, Anda juga akan terpukau oleh keindahan antara perpaduan laut.... besides you also will mesmerized by beauty between combination sea "Besides it, you will be mesmerized by the combination of sea ...."

\section{Bahasa Indonesia}

\begin{tabular}{lll}
\hline Selain itu, Anda juga & akan terpukau & oleh keindahan antara perpaduan laut.... \\
\hline Conj. Participant: Senser & Process: Mental & Participant: Phenomenon \\
\hline
\end{tabular}

\section{English}



From the fifteenth data classified into mental process as process of feeling, fourteen from them used the verb menikmati and one of them is terpukau. The fifteenth analyzed data have two participants: experiencer and phenomenon in each clause.

\subsubsection{Process of Perceiving (Through Five Senses)}

Process of perceiving is the second type of mental processes. This process involved three verbs: melihat, 
terdengar, and menyaksikan as described in the following.

(38) Di tempat ini, Anda dapat melihat ....

in place this you can see

"In this place you can see...."

\section{Bahasa Indonesia}

\begin{tabular}{ll}
\hline Di tempat ini, Anda & dapat melihat .... \\
\hline Circumstance Participant: Senser & Process: Mental \\
\hline
\end{tabular}

\section{English}

\begin{tabular}{lll}
\hline In this place & you & can see.... \\
\hline Circumstance & Participant: Senser & Process: Mental \\
\hline
\end{tabular}

(39) Hanya mungkin ucapan orang Belanda ketika itu terdengarnya oleh warga pribumi itu Santolo. Only maybe utterance people Dutch when they hear by citizen native the Santolo "Maybe, at that time, the native heard the Dutch uttered Santolo."

\section{Bahasa Indonesia}

\begin{tabular}{llll}
\hline Hanya mungkin ucapan orang terdengarnya ketika itu oleh warga pribumi itu Santolo.Belanda \\
\hline Circumstance & Process: Mental & Participant: Senser & Participant: Phenomenon \\
\hline
\end{tabular}

\section{English}

\begin{tabular}{lllll}
\hline \multicolumn{2}{l}{ Maybe, at that time, the native } & heard & the Dutch & uttered Santolo \\
\hline Circumstance & Participant: Senser & Process: Mental & Participant: Phenomenon & Process: Verbal Verbiage \\
\hline
\end{tabular}

(40) Sebab dari sana kita dapat menyaksikan keindahan pemandangan matahari tenggelam secara jelas. because from there we can see beauty scenery sun set with clear "From there, we can see the beauty of sunset clearly."

\section{Bahasa Indonesia}

\begin{tabular}{llll}
\hline Sebab dari sana & kita & dapat menyaksikan keindahan pemandangan matahari tenggelam secara jelas. \\
\hline Conj. Circumstance & Participant: Senser & Process: Mental & Participant: Phenomenon \\
\hline
\end{tabular}

\section{English}

\begin{tabular}{llll}
\hline From there, & we & can see & the beauty of sunset clearly \\
\hline Circumstance & Participant: Senser & Process: Mental & Participant: Phenomenon Circumstance \\
\hline
\end{tabular}

From the fourteenth data found, the present writer found the three verbs involved: they are melihat eleven data, terdengar one data, and menyaksikan two data. The participant involved in data can betwo participants: senser and phenomenon or senser or phenomenon only.

\subsection{Existential Processes}

The existential process is the fourth type of processes found in the Bahasa Indonesia tourism promotion texts. From the data collected, there are 12 data. From the twelve data involved four different verbs, they are $a d a$, terdapat, terhampar, and tersedia.

(41) Konon hal seperti itu hanya ada di dua tempat di dunia, ....

in the past matter like that only be in two place in world

"Somebody says, there are only two places in the world, in Santolo Garut and the other is in French." 
Bahasa Indonesia

\begin{tabular}{|c|c|}
\hline Konon hal seperti itu hanya ada & di dua tempat di dunia, \\
\hline Process: Existential & Participant: Existent \\
\hline
\end{tabular}

\section{English}

... there are only two places in the world .... Process: Existential Participant: Existent

(42) Di sisi pulau terdapat bangunan bekas dermaga ....

in side island be building old quay

"In the island side, there is a building, a quay...."

\section{Bahasa Indonesia}

\begin{tabular}{llll}
\hline $\begin{array}{l}\text { Di sisi pulau } \\
\text { tahun 1920. }\end{array}$ & terdapat & bangunan bekas dermaga pada masa pemerintahan kolonial Belanda sekitar \\
\hline Circumstance & Process: Existential & Participant: Existent & Circumstance \\
\hline
\end{tabular}

\section{English}

\begin{tabular}{|c|c|c|c|}
\hline In the island si & & a building, a quay & in Dutch government era in 1920 \\
\hline Circumstance & Process: Existential & Participant: Existent & Circumstantial \\
\hline
\end{tabular}

(43) Di pantai ini telah tersedia Penginapan dengan fasilitas AC dan TV, juga tersedia dengan fasilitas biasa. in beach this have available inn with facility AC and TV also available with facility usual "In this beach there is the Inn with AC and TV facility ...."

\section{Bahasa Indonesia}

\begin{tabular}{lll}
\hline Di pantai ini & telah tersedia & penginapan dengan fasilitas $A C$ dan $T V, \ldots$. \\
\hline Circumstance & Process: Existential & Participant: Existent \\
\hline
\end{tabular}

\section{English}

\begin{tabular}{ll}
\hline In this beach there is & the Inn with AC and TV facility .... \\
\hline Circumstance $\quad$ Process: Existential & Participant: Existent \\
\hline
\end{tabular}

From the four verbs involved in the existential process, the equivalence of the verb terdapat is the dominant (five data), tersedia (four data), ada (two data), and terhampar (one data).

\section{Conclusion}

From the data analyzed, the present writer concludes that

1) There are four types of processes found in Bahasa Indonesia tourism promotion texts and its equivalence in English as described in the following table.

\begin{tabular}{llll}
\hline No & Process & Data & $\%$ \\
\hline 1 & Material & 78 & 51.7 \\
2 & Relational & 33 & 21.9 \\
3 & Mental & 28 & 18.5 \\
4 & Existential & 12 & 7.9 \\
\hline Total & & 151 & 100 \\
\hline
\end{tabular}

2) The participant involve in Bahasa Indonesia tourism promotion texts and its equivalence in English are (a) Material processes: agent, goal, and beneficiary(b) Relational processes: carrier and attribute, (c) Mental processes: senser and phenomenon, and (d) Existential processes: existent 
3) The verb used in each clause containing material processes, relational processes, mental processes, and existential processes in Bahasa Indonesia tourism promotion texts and its equivalence in English are

\section{Material processes:}

Bahasa Indonesia

(i) agent-process: tenggelam, (ii) agent-process-goal: berkunjung mencari, dipadu, akan menemani, menyajikan, menjanjikan memberikan, menyimpan, menyuguhkan, (iii) agent - process - circumstance: memanjakan, berlabuh, menutup, melancong, (iv) agent - process - goal - circumstance: membentuk, (v) agent - process benefactive - circumstance: memberi, (vi) circumstance - agent - process - goal: dapat membeli, memecah, dapat memesan, menyediakan, terabaikan, (vii) goal - process - circumstance: dapat ditempuh, (viii) goal - process agent - circumstance: dikirimkan, dilakukan, digunakan.

\section{English}

(i) agent-process: set, (ii) agent-process-goal: visit to look for, were combined, will accompany, serve, promise to give, put, serve, (iii) agent - process - circumstance: spoil, anchor, can close, visit, (iv) agent - process - goal circumstance: shape, (v) agent - process - benefactive - circumstance: give, (vi) circumstance - agent - process goal: can buy, break, can order, serve, was ignored, (vii) goal -process-circumstance: can be through, (viii) goal - process - agent - circumstance: were sent, can be done, is used.

\section{Relational processes:}

Bahasa Indonesia:adalah, berasal dari, memiliki, mempunyai, mengandung, bisa menjadi, tampak, menyerupai, merupakan, berada, terletak, berlokasi.

English: is, comes from, have, contain, can become, seem, like, become, is, is located

\section{Mental processes:}

Bahasa Indonesia

(i) process of feeling: dapat menikmati, terpukau

(ii) process of perceiving: melihat, terdengar.

\section{English}

(i) process of feeling: can enjoy, will be mermerized

(ii) process of perceiving: can see, heard.

\section{Existential process:}

The verb involved in existential processes in Bahasa Indonesia are ada, terdapat, tersedia while in English is the verb be.

\section{References}

Bhattacherjee, A. (2012). Social Science Research: Principles, Methods, and Practices. Retrieved from http://scholarcommons.usf.edu/cgi/viewcontent.cgi?article $=1002 \&$ context $=0$ a_textbooks

Biber, D., \& Conrad, S. (2009). Register, Genre, and Style. New York: Cambridge University Press. http://dx.doi.org/10.1017/CBO9780511814358

Bloor, T., \& Bloor, M. (2004). The Functional Analysis of English. London: Hodder Education.

Decrop, A. (2007). The influence of message format on the effectiveness of print advertisements for tourism destinations. International Journal of Advertising: The Review of Marketing Communications, 26(4), 505-525.

Deterding, D. H., \& Poedjosoedarmo, G. R. (2001). The Grammar of English. Singapore: Prentice Hall.

Emilia, E. (2014). Introducing Functional Grammar. Bandung: PT Dunia Pustaka.

Gerot, L., \& Wignell, P. (1995). Making Sense of Functional Grammar. Sydney: Gerd Stabler.

Halliday, M. A. (1985). An Introduction to Functional Grammar. London: Hodder Arnold.

Halliday, M. A. K., \& Matthiessen, C. M. I. M. (2004). An introduction to functional grammar. Lingua, 3. http://doi.org/10.1016/0024-3841(86)90084-7

Humphrey, S., Love, C., \& Loise, D. (2014). Working Grammar. Sydney: Pearson.

Martin, J. R. (2011). Systemic Functional Linguistics. In K. Hyland \& B. Paltridge (Eds.), The Continuum 
Companion to Discourse Analysis (pp. 101-119).

Martin, J. R., Matthiessen, C. M. I. M., \& Painter, C. (1997). Working with Functional Grammar. London: Arnold.

Matthiessen, C. M. I. M., Teruya, K., \& Lam, M. (2010). Key Terms in Systemic Functional Linguistics. London: Continuum.

Sujatna, E. T. S. (2012). Applying Systemic Functional Linguistics to Bahasa Indonesia Clauses. International Journal of Linguistics, 4(2), 134-146. http://doi.org/10.5296/ijl.v4i2.1506

Sujatna, E. T. S. (2013). Understanding Systemic Functional Linguistics. Bandung: Unpad Press.

Sukma, B. P., \& Sujatna, E. T. S. (2014). Interpersonal Metadiscourse Markers in Opinion Articles: A Study of Texts Written by Indonesian Writers. International Journal of Applied Linguistics \& English Literature, 3(2), 16-21. http://doi.org/10.7575/aiac.ijalel.v.3n.2p.16

Sunjayadi, A. (2008). Mengabadikan Estetika Fotografi dalam Promosi Pariwisata Kolonial Hindia Belanda. Wacana, 10(2), 300-315. http://dx.doi.org/10.17510/wjhi.v10i2.199

\section{Copyrights}

Copyright for this article is retained by the author(s), with first publication rights granted to the journal.

This is an open-access article distributed under the terms and conditions of the Creative Commons Attribution license (http://creativecommons.org/licenses/by/3.0/). 